\title{
Severity of alcohol use and problem behaviors among school-based youths in Puerto Rico
}

\author{
William W. Latimer, ${ }^{1}$ Vanessa Cecilia Rojas, ${ }^{1}$ \\ and Brent Edward Mancha ${ }^{1}$
}

Suggested citation Latimer WW, Rojas VC, Mancha BE. Severity of alcohol use and problem behaviors among schoolbased youths in Puerto Rico. Rev Panam Salud Publica. 2008;23(5):325-32.

\begin{abstract}
Objectives. The present study sought to: (a) categorize youths into groups based on their level of alcohol use and number of symptoms of alcohol abuse and dependence defined in the Diagnostic and Statistical Manual of Mental Disorders (DSM-IV), and (b) examine whether these categories were associated with other problem behaviors in which youths engage (marijuana use, sexual intercourse, and having been arrested or having trouble with the law). Methods. The study is based on a cross-sectional survey administered to 972 school-based youths from one middle school and one high school in San Juan, Puerto Rico. Youths were categorized based on their alcohol use and alcohol problems. These categories were then examined for associations with lifetime marijuana use, lifetime sexual intercourse, and having been arrested or having had trouble with the law in the past year. The original eight categories of alcohol use were collapsed into six categories based on the results.

Results. For virtually every group characterized by higher severity of alcohol use and alcohol problems, researchers found an increasing prevalence of marijuana use in their lifetimes, increasing odds of sexual intercourse in their lifetimes, and having had trouble with the law in the past year.

Conclusions. Knowing about variations in alcohol use and alcohol problems may be instrumental in measuring the degree to which youths may also be engaging in a range of other elevated risk behaviors and a progression to more serious forms of alcohol and drug use.
\end{abstract}

Key words Adolescent behavior, alcohol-related disorders, alcoholism, classification, risk behaviors, Puerto Rico.

Adolescent alcohol use is an important public health concern because

\footnotetext{
1 Johns Hopkins Bloomberg School of Public Health, Department of Mental Health, Baltimore, Maryland, U.S.A. Send correspondence to: W. Latimer, Johns Hopkins Bloomberg School of Public Health, Department of Mental Health, 624 North Broadway, Baltimore, MD 21205, United States; Tel: 410206-5805; Fax: 410-955-0237; e-mail: wlatimer@ jhsph.edu.
}

morbidities and mortality continue to be associated with it, including unintended/early pregnancy (1), HIV / AIDS infection (2), violence (3), and traffic fatalities $(4,5)$. Alcohol use among youths is prevalent worldwide. Researchers have reported problematic use in Russia (6), South Africa (7), Mexico (8), the United States (9), and Puerto Rico $(9,10)$, which is the focus of this study. Despite efforts to curtail it, alcohol use among youths in Puerto Rico remains high (10). Research is needed to estimate the need for alcohol prevention and treatment programs and to inform these programs on how to best target youths. This study set out to examine the prevalence of alcohol use and alcohol problems and their association to other 
problem behaviors in a school-based sample of Puerto Rican youths.

Although older studies exist (11), there have been few recent studies examining alcohol use $(10,12-14)$ or alcohol-related problems (9, 15-17) among Puerto Rican adolescents. Many of these surveys have utilized self-reported alcohol use frequencies for varying time periods, such as lifetime use, use in the past year, or use in the past 30 days as a means to measure the range of alcohol use problems (10, 12-14). The Consulta Juvenil survey, a prominent population-based probability survey of Puerto Rican youths, has collected data on adolescent substance use for many years (18-21) and recently found that the prevalence of lifetime alcohol use ranged from $30.4 \%$ for 12 year olds to $81.7 \%$ for 17 year olds (10). Additionally, the Youth Risk Behavior Surveillance System recently found that $67 \%$ of Puerto Rican youths had used alcohol in their lifetime and $22.5 \%$ had five or more drinks on one occasion in the past 30 days (13).

Some studies have solely used measures of frequency of alcohol use, other studies of this population have incorporated instruments to measure the prevalence of alcohol use disorders $(9,15-17)$, such as alcohol abuse or dependence as defined by the Diagnostic and Statistical Manual of Mental Disorders (DSM-IV-TR) (22). For example, one study estimated that $6.4 \%$ of Puerto Rican youths between 15 and 18 years old met a diagnosis of alcohol abuse or dependence in their lifetime (9). Another reported that among 15-21 year olds, $10.2 \%$ had alcohol abuse or dependence in their lifetimes and $6.7 \%$ had alcohol abuse or dependence in the past year (16). While studies differ slightly in their estimates of alcohol abuse and dependence, they consistently show that a sizable number of Puerto Rican youths experience problems with their alcohol use.

We are aware of only two relatively recent studies that have examined the relationship between adolescent alcohol use and problem behaviors in Puerto Rico $(23,24)$. One study found that youth who had multiple sex partners reported more alcohol use (23). Another study found that alcohol use was associated with violent behavior in adolescents (24). More research is warranted to examine the relationship between alcohol use and problem behavior. Knowing an adolescent's level of alcohol use may allow one to predict their engagement in other behaviors.

Problem behavior theory seeks to explain adolescent drinking behavior from a psychosocial perspective, incorporating the personality, perceived environment, and behavior of the young drinker. This theory states that youths who engage in one problem behavior, such as alcohol use, are at risk of engaging in other problem behaviors, such as problem drinking, drug use, sexual intercourse, and deviant behaviors $(25,26)$. Alcohol use is one part of a syndrome of problem behavior engagement which is linked to negative distal outcomes $(25,26)$, such as academic failure, unintended pregnancy, sexually transmitted infections, and delinquency.

The present study expands on the current literature on Puerto Rican youths by: (a) categorizing youths into groups based on their frequency of alcohol use and the number of DSM-IV symptoms of abuse and dependence they reported, and $(b)$ examining the association between these alcohol groups and youths' self-report of their engagement in other problem behaviors, specifically lifetime marijuana use, lifetime sexual activity, and having been arrested or in trouble with the law in the last year. Based on previous work, we hypothesized that Puerto Rican youths will exhibit a range in frequency of alcohol use and alcohol problems and that those reporting more alcohol use and problems will also report higher engagement in problem behaviors.

\section{MATERIALS AND METHODS}

\section{Participants and procedure}

The International Longitudinal Survey of Adolescent Health is a confidential survey designed to assess risk and protective factors associated with a range of health behavior outcomes in adolescence, including drug use, sexual behavior, psychiatric problems, and school achievement (14, 27). All students attending one middle school (grades 7-9) and one high school (grades 10-12) in a community in San Juan, Puerto Rico, were invited to participate in the study. The survey was conducted in the spring of 2000. Of those invited to participate, less than $1 \%$ of the parents or the students refused to participate, and another $11 \%$ were absent on the survey administration day. The survey response rate was $88 \%$ with a total of 989 students completing the survey. Of the 989 who completed the survey, $2 \%(n=17)$ were excluded from the analyses because they reported use of a fictitious drug item or had an inconsistent pattern of responses throughout the survey. The final sample included 972 youths; $442(45.5 \%)$ were middle school students and $530(55.5 \%)$ were high school students. The youths ranged in age from 11 to 19 years old $($ mean $=14.9$; standard deviation $=$ 1.7); the majority was Hispanic (95.9\%) and female (57.2\%) (see Table 1).

The procedures for this study, including survey development using forward and backward translation into Spanish, survey administration, and selection of schools, are described in more detail elsewhere (27). Briefly, the city and schools were randomly chosen from among the five largest cities in Puerto Rico and the five largest schools in that city. The procedures for the survey administration were adapted from the confidential survey methodology used in the Monitoring the Future Study (28), a survey conducted in the United States that is frequently cited as a source of information on adolescent health. Study assent forms were signed by all students who participated in the study. The survey and study procedures were reviewed and approved by the University of Minnesota Review Board, the Superintendent of each school, and an ad hoc review board (including the principal, teachers, and parents) formed at each school. 
TABLE 1. Characteristics of 972 school-based youths included in survey on alcohol use and problem behaviors, Puerto Rico, 2000

\begin{tabular}{lrc}
\hline Characteristic & No. & $\%$ \\
\hline Gender & & \\
$\quad$ Female & 556 & 57.2 \\
$\quad$ Male & 416 & 42.8 \\
Age & & \\
$\quad 11-14$ years & 379 & 39.0 \\
$\quad$ 15-19 years & 593 & 61.0 \\
Ethnicity & 7 & \\
$\quad$ White & 932 & 0.7 \\
$\quad$ Hispanic & 33 & 95.9 \\
Other & & 3.4 \\
School & 442 & 45.5 \\
$\quad$ Middle school & 530 & 54.5 \\
High school & & \\
\hline
\end{tabular}

\section{Measures}

The items in this survey were derived mainly from the Personal Experience Inventory (PEI) (29) and the Adolescent Diagnostic Interview (ADI) (30). The PEI has been widely used in United States school and clinic settings and has shown good psychometric properties $(29,31)$. The ADI has also shown moderate to high reliability and validity and has been extensively used in the United States $(30,31)$. While the survey was originally developed in English, it was translated into Spanish using forward and backward translation (27).

\section{Problem behavior variables}

Three variables, including marijuana use frequency, sexual intercourse, and having been arrested were selected based on their association to the behavior system of problem behavior theory $(25,26)$. These variables were derived from the PEI (29). Participants were asked about frequency of marijuana use in their lifetime and chose from seven response choices, ranging from never to 40 or more times. This measure was dichotomized for the purposes of this analysis ("never used in lifetime" versus "any use in lifetime"). Another item asked participants if they had ever had sexual intercourse in their lifetime ("yes" or "no"). Another item asked whether respondents had been arrested or had trouble with the law in the past 12 months ("yes" or "no"). Of the 972 in the final sample, 102 youths $(10.5 \%)$ had missing values on lifetime sexual intercourse and 45 youths (4.6\%) had missing values on having been arrested. Cases with missing data on the outcome were dropped from the logistic regression analyses.

\section{Frequency of alcohol use}

Survey items assessing the frequency of alcohol use were derived from the PEI (29). Participants responded to items inquiring about frequency of alcohol use in their lifetime and in the past 12 months by selecting from seven response choices, ranging from never to 40 or more times. For this analysis, lifetime alcohol use was dichotomized into "never used in lifetime" versus "any use in lifetime." Alcohol use in the past 12 months was categorized into three groups: "no use in the past year," "used alcohol between one and nine times in the past year," and "used alcohol ten or more times in the past year."

\section{Alcohol abuse and dependence symptoms}

Participants responded to 20 items asking about the frequency of prob- lems related to alcohol use that they experienced in the past year by selecting from three response choices: "never," "one time," or "two or more times." For this analysis, each item was dichotomized into "never" versus "one or more times." Eleven survey items addressed DSM-IV alcohol abuse symptoms and nine items addressed DSM-IV alcohol dependence symptoms (22). These items were adapted from the ADI (30). An example item addressing abuse is: "During the past 12 months, have you skipped school because of alcohol use?" The 20 items were combined into two categories: those reporting one or two abuse symptoms or one or two dependence criteria and those reporting three or more abuse symptoms or three or more dependence criteria.

\section{Alcohol use categories}

We sought to define categories of youths based on frequency of alcohol use and consequences associated with use. Following the DSM-IV, ${ }^{2}$ we first identified subjects reporting three or more dependence criteria to define alcohol dependence. However, some studies show that the number of symptoms matter more than the type of symptom (abuse versus dependence) when measuring the severity of

\footnotetext{
2 The DSM-IV-TR defines alcohol abuse as a maladaptive pattern of recurrent alcohol use leading to clinically significant impairment, as manifested by one (or more) of the following problems in the same 12-month period: a failure to fulfill major role obligations at work, school, or home; recurrent use in physically hazardous situations; recurrent alcohol-related legal problems; and continued use despite having social or interpersonal problems caused or exacerbated by use. A diagnosis of alcohol abuse is preempted by a diagnosis of alcohol dependence. Alcohol dependence is defined as a maladaptive pattern of alcohol use, leading to clinically significant impairment, as manifested by three (or more) of the following symptoms in the same 12-month period: tolerance; withdrawal; using larger amounts or over a longer period than intended; desire to or unsuccessful efforts to cut down on use; a great deal of time is spent trying to obtain, use, or recover from the effects of alcohol; important social, occupational, or recreational activities are given up or reduced because of use; and use is continued despite having a physical or psychological problem caused by or exacerbated by alcohol use. (Adapted from the American Psychiatric Association [APA], Diagnostic and statistical manual of mental disorders, 4 th ed., text revision; Washington, D.C.: APA, 2000; pp. 197-199.)
} 
TABLE 2. Prevalence of school-based youths in eight alcohol use groups and chi-square and two-sided Fisher's exact test comparisons of each category on their report of lifetime marijuana use, Puerto Rico, 2000

\begin{tabular}{|c|c|c|}
\hline & $\begin{array}{l}\text { No marijuana } \\
\text { use in lifetime } \\
\end{array}$ & $\begin{array}{c}\text { Have used } \\
\text { marijuana in lifetime }\end{array}$ \\
\hline Alcohol use categories & No. (\%) & No. (\%) \\
\hline No lifetime alcohol use & 310 (9.4\%) & $2\left(0.6 \%{ }^{A}\right)$ \\
\hline Lifetime alcohol use: none in the past year & $138(96.5 \%)$ & $5\left(3.5 \%{ }^{\mathrm{AB}}\right)$ \\
\hline Used alcohol 1-9 times in the past year & $272(87.2 \%)$ & $40\left(12.8 \%{ }^{\mathrm{BC}}\right)$ \\
\hline Used alcohol $10+$ times in the past year & $38(73.1 \%)$ & $14(26.9 \% \mathrm{CD})$ \\
\hline $1-2$ abuse symptoms & $51(78.5 \%)$ & $14(21.5 \% \mathrm{CD})$ \\
\hline $1-2$ dependence criteria & $24(64.9 \%)$ & $13(35.1 \% \mathrm{D})$ \\
\hline $3+$ abuse symptoms & $11(50.0 \%)$ & $11(50.0 \% \mathrm{DE})$ \\
\hline $3+$ dependence criteria & $6(20.7 \%)$ & $23(79.3 \% \mathrm{E})$ \\
\hline Total & $850(87.4 \%)$ & $122(12.6 \%)$ \\
\hline
\end{tabular}

Note: Chi-square or two-sided Fisher's exact tests (when expected cell sizes were $<5$ ) were used to compare each alcohol group on their percentage of lifetime marijuana use. Categories that share superscripts refer to comparisons that are not statistically different, such as categories one $\left(0.6 \%{ }^{\mathrm{A}}\right)$ and two $(3.5 \% \mathrm{AB})$. Categories with different superscripts refer to statistically significant differences at $P<0.0018$, such as categories one $\left(0.6 \%{ }^{\mathrm{A}}\right)$ and three $\left(12.8 \%{ }^{\mathrm{BC}}\right)$.

problems with alcohol use $(32,33)$, so we created another group of youths reporting three or more abuse symptoms. We also created a group of youths having one or two abuse symptoms and then another group reporting one or two dependence criteria, whom some researchers have labeled "diagnostic orphans" (34). Youths who did not report any symptoms of abuse or dependence were classified according to their frequency of alcohol use in their lifetime and in the past year. Specifically, these groups were: "no use in lifetime," "lifetime use but none in the past year," "used between one and nine times in the past year," and "used ten or more times in the past year." This resulted in eight groups of youths (see Table 2).

Before finalizing the alcohol use categories we checked the validity of the groupings to see if any categories could be collapsed together. Lifetime marijuana use was applied as a criterion variable to finalize the development of the alcohol use categories. To do this we evaluated whether the groups differed by their prevalence of lifetime marijuana use. We found that youths reporting one or two abuse symptoms and those reporting one or two dependence criteria did not have statistically different rates of marijuana use (see Table 2). Similarly, those reporting three or more abuse symptoms and those reporting three or more dependence criteria did not have statistically different rates of marijuana use (see Table 2). Based on these results those reporting one or two alcohol abuse symptoms were combined with those reporting one or two alcohol dependence criteria and those reporting three or more alcohol abuse symptoms were combined with those reporting three or more alcohol dependence criteria. This resulted in the final grouping of six categories: no alcohol use in lifetime (and no DSM-IV symptoms); alcohol use in lifetime but none in the past year (and no DSM-IV symptoms); used alcohol one to nine times in the past year (and no DSM-IV symptoms); used alcohol ten or more times in the past year (and no DSM-IV symptoms); reported one or two DSMIV abuse symptoms or dependence criteria (and alcohol use in lifetime); and reported three or more DSM-IV abuse symptoms or dependence criteria (and alcohol use in lifetime) (see Table 3).

\section{Statistical analysis}

First, to make the final determination on the alcohol use categories, we examined the relationship between the eight alcohol use categories and lifetime marijuana use. Due to small sample sizes in several of the categories (especially the abuse and dependence categories) we were not able to stratify by gender or school/grade status. We conducted multiple $2 \times 2$ chi-square tests or two-sided Fisher's exact tests comparing each of the eight categories on their report of lifetime marijuana use. Because the chi-square test is not recommended for comparisons with low cell sizes, we employed the Fisher's exact test when the chi-square comparisons had at least one expected cell frequency of less than five (35). Because we conducted 28 comparisons

TABLE 3. Association of alcohol use group status and lifetime sexual intercourse among 972 students, Puerto Rico, 2000

\begin{tabular}{|c|c|c|c|}
\hline Alcohol use groups & $\begin{array}{c}\text { No. of } \\
\text { participants (\%) }\end{array}$ & $\begin{array}{l}\text { Prevalence of sexual } \\
\text { intercourse in lifetime }\end{array}$ & $\begin{array}{c}\text { Adjusted odds ratio } \\
(95 \% \mathrm{Cl})^{\mathrm{a}}\end{array}$ \\
\hline No lifetime alcohol use & $312(32.1 \%)$ & $10.8 \%$ & 1.0 \\
\hline Lifetime alcohol use, none in the past year & $143(14.7 \%)$ & $15.2 \%$ & $1.3(0.7-2.5)$ \\
\hline Used alcohol 1-9 times in the past year & $312(32.1 \%)$ & $29.3 \%$ & $3.3(2.0-5.2)^{\mathrm{b}}$ \\
\hline Used alcohol $10+$ times in the past year & $52(5.4 \%)$ & $66.0 \%$ & $13.8(6.7-28.7)^{\mathrm{b}}$ \\
\hline 1-2 abuse or dependence symptoms & $102(10.5 \%)$ & $37.1 \%$ & $4.1(2.3-7.5)^{b}$ \\
\hline $3+$ abuse or dependence symptoms & $51(5.2 \%)$ & $66.7 \%$ & $13.5(6.2-29.4)^{b}$ \\
\hline
\end{tabular}

\footnotetext{
${ }^{a}$ Adjusted for age and gender.
}

b $P<0.001$ 
we used a Bonferroni-corrected $P$ value of $P<0.0018$ to determine statistical significance. Two categories were considered significantly different on their report of lifetime marijuana use if $P<0.0018$. The chi-square and Fisher's exact test comparisons were conducted using SPSS, version 13.0 (36).

Finally, after collapsing two of the groups, the final six categories of the alcohol grouping were compared for two different problem behaviors: (a) having sexual intercourse in their lifetimes and $(b)$ having been arrested or in trouble with the law in the past year. Again, small sample and cell sizes precluded stratification by gender or by school/grade status. Using Stata, version 8.0 (37), we carried out multiple logistic regressions to examine the association between the six alcohol categories and problem behavior, adjusting for age and gender (37). Indicator variables were created for the six categories and entered into the two logistic regressions.

\section{RESULTS}

Table 2 shows the chi-square and Fisher's exact test analyses comparing prevalence of lifetime marijuana use for each alcohol category. We found that students reporting no lifetime alcohol use reported significantly lower proportions of lifetime marijuana use $(0.6 \%)$ when compared to six out of the seven other alcohol use groups, including students who had used alcohol one to nine times in the past year $\left(12.8 \%, \chi^{2}=36.86\right.$, df $\left.=1, P<0.001\right)$ and students who used alcohol ten or more times in the past year $(26.9 \%, P<$ 0.001) (see Table 2).

Students reporting no lifetime alcohol use and students reporting lifetime alcohol use but none in the past year, reported lifetime marijuana use rates that were not statistically different $(0.6 \%$ and $3.5 \%$, respectively). Similarly, students reporting lifetime alcohol use but no use in the past year and students who used alcohol one to nine times in the past year reported lifetime marijuana use rates that were not statistically different $(3.5 \%$ and $12.8 \%$, re- spectively). However, students reporting lifetime alcohol use but none in the past year exhibited significantly lower proportions of lifetime marijuana use when compared with each of the remaining groups that were characterized by higher levels of alcohol use and alcohol problems, including students who used 10 or more times in the past year $\left(3.5 \%\right.$ versus $26.9 \%, \chi^{2}=$ 23.80, df $=1, P<0.001)$.

Students reporting three or more alcohol dependence criteria had a lifetime marijuana use prevalence of $79.3 \%$, significantly greater than all other alcohol categories. This included students reporting one or two alcohol abuse symptoms (79.3\% versus $21.5 \%$, $\left.\chi^{2}=28.04, \mathrm{df}=1, P<0.001\right)$ and students with one or two alcohol dependence criteria $(79.3 \%$ versus $35.1 \%$, $\left.\chi^{2}=12.80, \mathrm{df}=1, P<0.001\right)$. The prevalence of lifetime marijuana use among students reporting three or more alcohol abuse symptoms was 50\%.

Grouping of six alcohol use categories. Based on the chi-square and Fisher's exact test results, we combined students with one or two abuse symptoms and one or two dependence criteria into one group. Similarly, we combined students with three or more abuse symptoms and three or more dependence criteria into one group. The remaining four groups were retained: no use in lifetime, lifetime use but none in the past year, used between one and nine times in the past year, and used ten or more times in the past year. The new grouping for six categories of alcohol use is shown in Table 3.

Alcohol use and sexual intercourse. With adjustment for age and gender, the odds of lifetime sexual intercourse was significantly greater among students who reported having used alcohol one to nine times in the past year $(\mathrm{OR}=3.3,95 \% \mathrm{CI}=2.0-5.2)$, students having used 10 or more times in the past year $(\mathrm{OR}=13.8,95 \% \mathrm{CI}=$ 6.7-28.7), students reporting one or two alcohol abuse or one or two alcohol dependence symptoms $(\mathrm{OR}=4.1$, $95 \%$ CI $=2.3-7.5)$, and students report- ing three or more alcohol abuse or three or more alcohol dependence symptoms $(\mathrm{OR}=13.5,95 \% \mathrm{CI}=$ 6.2-29.4) when compared to students with no alcohol use in their lifetime (see Table 3). The odds of having had sexual intercourse among students reporting alcohol use in their lifetime but none in the past year was not significantly different from students reporting no alcohol use in their lifetime. In addition, males were significantly more likely than females to report having had sex $(\mathrm{OR}=2.6,95 \% \mathrm{CI}=$ 1.8-3.7). Also, for each year older, youths were approximately 30\% more likely to report having had sexual intercourse $(\mathrm{OR}=1.3,95 \% \mathrm{CI}=1.1-1.4)$.

Alcohol use and having been arrested. There was a similar pattern of results between the alcohol use categories and having been arrested or in trouble with the law. After adjusting for age and gender, the odds of having been arrested was significantly greater among students having used alcohol one to nine times in the past year $(\mathrm{OR}=5.0$, $95 \% \mathrm{CI}=1.1-23.8)$, students reporting one or two alcohol abuse or one or two alcohol dependence symptoms (OR = $8.2,95 \% \mathrm{CI}=1.5-44.6$ ), and students reporting three or more alcohol abuse or three or more alcohol dependence symptoms $(\mathrm{OR}=35.5,95 \% \mathrm{CI}=$ 7.0-178.7) when compared with students with no alcohol use in their lifetimes (see Table 4). The odds of having been arrested among students reporting alcohol use in their lifetimes but none in the past year and students having used alcohol 10 or more times in the past year was not significantly different from students reporting no alcohol use in their lifetime. Also, males were significantly more likely than females to report having been arrested $(\mathrm{OR}=3.2,95 \% \mathrm{CI}=1.3-7.5)$. Age was not significantly associated with having been arrested $(\mathrm{OR}=1.0$, $95 \%$ CI $=0.8-1.3$ ).

\section{DISCUSSION}

The severity of problems with alcohol use among Puerto Rican adoles- 
TABLE 4. Association of alcohol use group status and past year arrest/law trouble among 972 students, Puerto Rico, 2000

\begin{tabular}{lccc}
\hline \multicolumn{1}{c}{ Alcohol use groups } & $\begin{array}{c}\text { No. of } \\
\text { participants (\%) }\end{array}$ & $\begin{array}{c}\text { Prevalence of trouble } \\
\text { with the law (\%) }\end{array}$ & $\begin{array}{c}\text { Adjusted odds ratio } \\
(95 \% \mathrm{Cl})^{\mathrm{a}}\end{array}$ \\
\hline No lifetime alcohol use & $312(32.1 \%)$ & $0.6 \%$ & 1.0 \\
Lifetime alcohol use, none in the past year & $143(14.7 \%)$ & $0.8 \%$ & $1.3(0.1-14.4)$ \\
Used alcohol 1-9 times in the past year & $312(32.1 \%)$ & $3.0 \%$ & $5.0(1.1-23.8)^{\mathrm{b}}$ \\
Used alcohol 10+ times in the past year & $52(5.4 \%)$ & $2.3 \%$ & $3.7(0.3-43.2)$ \\
$1-2$ abuse or dependence symptoms & $102(10.5 \%)$ & $5.3 \%$ & $8.2(1.5-44.6)^{\mathrm{b}}$ \\
3+ abuse or dependence symptoms & $51(5.2 \%)$ & $19.2 \%$ & $35.5(7.0-178.7)^{\mathrm{c}}$ \\
\hline
\end{tabular}

a Adjusted for age and gender.

b $P<0.05$.

c $P<0.001$.

cents was examined in this study by creating an alcohol-use grouping based on self-reported alcohol use frequency and DSM-related symptoms of alcohol abuse and dependence. Initially, we used eight alcohol use categories but collapsed two of the categories based on the results. We then evaluated whether the final sixcategory grouping was associated with two other problem behaviors.

For virtually every group characterized by higher severity of problems with alcohol use we found increased prevalence of lifetime marijuana use, increased odds of having sexual intercourse in their lifetimes, and arrest or trouble with the law in the past year. The more alcohol consumed in a year and the more alcohol-related symptoms adolescents reported, the higher the prevalence of marijuana use and the higher the odds of having engaged in sexual intercourse and having been arrested. However, those who reported using alcohol 10 or more times in the past year showed an anomalous prevalence of problem behaviors, slightly higher or lower than what fit with the pattern seen in the other categories (e.g., a higher prevalence of problem behavior engagement with higher alcohol use and alcohol problems). The low sample size in this category likely contributed to these anomalies. In addition, males were more likely than females to report having had sex and having been arrested. Also, for each year older youths were, the more likely they were to report having had sex. These associations are not surprising given research suggesting that males generally engage in more problem behaviors than females $(24,38)$ and that sexual intercourse becomes more prevalent with older age (38).

Our findings also suggest that the number of symptoms rather than the type of symptom reported (i.e., abuse versus dependence) may be more descriptive of the severity of problems with alcohol use in an individual. Specifically, youths reporting three or more abuse symptoms and those reporting three or more dependence criteria had rates of lifetime marijuana use that were not statistically different. The same was true for those reporting one or two abuse symptoms and those reporting one or two dependence criteria. These results are consistent with research that does not empirically support the diagnostic distinction between alcohol abuse and dependence in youths $(32,33)$. While this was an interesting and unexpected finding, this study was not designed to answer this question per se, and future studies may offer insight into whether number or type of symptom is more important in determining severity of problems with alcohol use.

While the results of this study are consistent with previous studies showing that alcohol use was associated with marijuana use (39), multiple sex partners (23), and violent behavior (24), this is the first study to our knowledge to investigate the association between several variations in alcohol use and alcohol problems and problem behaviors. Our results are also consistent with research supporting the validity of various levels of al- cohol use and alcohol problems among adolescents $(10,40)$. The present study found that almost $68 \%$ of youths have used alcohol in their lifetime which is consistent with previous studies suggesting that between $49 \%$ and $67 \%$ of youths have used alcohol in their lifetime $(12,13,17)$. The present study also found that around $16 \%$ of youths have at least one symptom of past year abuse or dependence, which is not consistent with previous studies suggesting that between $6.4 \%$ and $6.7 \%$ meet criteria for either lifetime or past year abuse or dependence $(9,16)$. The stark difference between estimates could be due to differences in the samples or in the measurement of alcohol abuse and dependence. The ADI was used in this study and may have a relatively low threshold for symptom reporting. These estimates are, however, crucial to estimating the resources needed for indicated alcohol and drug prevention interventions and treatment.

The present study had some noteworthy limitations. Our sample was taken from two schools in one community in San Juan, Puerto Rico, and our sample is likely not representative of the entire population of Puerto Rico. In addition, our sample was schoolbased and did not include adolescents who dropped out or skipped school and who are at greater risk for substance disorders and other problem behaviors (41). Further, given the cross-sectional analyses performed, we were not able to examine the stability of group membership over time or investigate across-time prediction 
of problem behaviors by group membership. Additionally, because of small sample sizes we could not examine the associations stratified by other important variables such as gender or middle/high school. Finally, as with other studies of this kind, we relied solely on students' self-report of alcohol use and risk behaviors. Still, extant research has supported the validity of adolescent self-report (28) and the present study incorporated both valid scales and response consistency checks in an effort to eliminate invalid responders.

\section{Conclusion}

The findings of this study suggest that knowing about variations in adolescent experimentation with alcohol and associated problems may be instrumental in measuring the degree to which youths may also be engaging in a range of other risk behaviors and a progression to more serious forms of alcohol and drug use $(38,40)$. Such information may be crucial to the targeting of selected and indicated prevention programs.

Acknowledgments. The research and preparation of this article were supported by the United States National Institute on Drug Abuse (Grants DA00254 and DA007292) and the National Institute of Mental Health (Grants MH19545 and MH14592).

\section{REFERENCES}

1. Naimi TS, Lipscomb LE, Brewer RD, Gilbert $\mathrm{BC}$. Binge drinking in the preconception period and the risk of unintended pregnancy: implications for women and their children. Pediatrics. 2003;111(5 Pt 2):1136-41.

2. Grossman M, Kaestner R, Markowitz S. An investigation of the effects of alcohol policies on youth STDs. Adv Health Econ Health Serv Res. 2005;16:229-56.

3. Stafstrom M. Kick back and destroy the ride: alcohol-related violence and associations with drinking patterns and delinquency in adolescence. Subst Abuse Treat Prev Policy. 2007; 2:18. Available from: http://www.substance abusepolicy.com/content/2/1/18. Accessed 14 January 2008.

4. United States Department of Health and Human Services, Centers for Disease Control and Prevention (CDC). Involvement by young drivers in fatal alcohol-related motorvehicle crashes-United States, 1982-2001. Morb Mortal Wkly Rep. 2002;51(48):1089-91. Available from: http://www.cdc.gov/mmwr/ preview/mmwrhtml/mm5148a2.htm. Accessed 14 January 2008.

5. Traffic Safety Commission of Puerto Rico. El problema del alcohol y su relación con los choques de tránsito en Puerto Rico. Santurce, Puerto Rico: Traffic Safety Commission; 1999.

6. Bokhan NA, Mandel AI, Gusamov RR. Mental and behavioral disorders in substance use among adolescents under conditions of the Far North. Alaska Med. 2007;49(2 Suppl):251-4.

7. Reddy P, Resnicow K, Omardien R, Kambaran N. Prevalence and correlates of substance use among high school students in South Africa and the United States. Am J Public Health. 2007;97(10):1859-64.

8. México, Secretaría de Salud (SSA). Encuesta nacional de adicciones 2002. Mexico, D.F.: SSA; 2004.

9. Warner LA, Canino G, Colon HM. Prevalence and correlates of substance use disorders among older adolescents in Puerto Rico and the United States: a cross-cultural comparison. Drug Alcohol Depend. 2001;63(3):229-43.

10. Moscoso MR, Colon HM, Parrilla I, Reyes JC. El uso de substancias en los escolares puerto- rriqueños. Consulta Juvenil V, 2000-2002. Bayamón, Puerto Rico: Administración de Servicios de Salud Mental y Contra la Adicción, Departamento de Medicina de Familia y Salud Comunal, Universidad Central del Caribe; 2003.

11. Robles R, Martinez R, Moscoso M. Drug use among public and private secondary school students in Puerto Rico. Int J Addict. 1979; 14(2):243-58.

12. Maldonado-Molina MM, Collins LM, Lanza ST, Prado G, Ramirez R, Canino G. Patterns of substance use onset among Hispanics in Puerto Rico and the United States. Addict Behav. 2007;32(10):2432-7.

13. United States Department of Health and Human Services, Centers for Disease Control and Prevention, National Center for Chronic Disease Prevention and Health Promotion. Youth Risk Behavior Surveillance System, Youth Online: Comprehensive Results [Internet site]. Available from: http://apps.nccd. cdc.gov/yrbss. Accessed 9 January 2008.

14. Latimer WW, Floyd LJ, Vasquez M, O’Brien M, Arzola A, Rivera N. Substance use among school-based youths in Puerto Rico: differences between gender and grade levels. Addict Behav. 2004;29(8):1659-64.

15. Colon HM, Robles RR, Canino G, Sahai H. Prevalence and correlates of DSM-IV substance use disorders in Puerto Rico. Bol Asoc Med P R. 2002;93(1-12):12-22.

16. Jackson-Moya I. Co-occurrence of psychiatric syndromes and substance use disorders among Puerto Rican adolescents. Dissertation Abstracts International Section A: Humanities and Social Sciences. 2000;61(5-A):2039.

17. Canino G, Shrout PE, Rubio-Stipec M, Bird HR, Bravo M, Ramirez R, et al. The DSM-IV rates of child and adolescent disorders in Puerto Rico: prevalence, correlates, service use, and the effects of impairment. Arch Gen Psychiatry. 2004;61(1):85-93.

18. Robles R, Moscoso M, Colon H, Garcia M, Rebollo J. El uso de substancias en los escolares puertorriqueños. Hato Rey, Puerto Rico: Instituto de Investigaciones, Administración de Servicios de Salud Mental y Contra la Adic- ción, Departamento de Medicina de Familia y Salud Comunal, Universidad Central del Caribe; 1991.

19. Robles R, Moscoso MR, Colon HM, Garcia M, Rebollo J, Parrilla I. El uso de substancias en los escolares puertorriqueños. Consulta Juvenil II, 1992-93. Hato Rey, Puerto Rico: Instituto de Investigaciones, Administración de Servicios de Salud Mental y Contra la Adicción, Departamento de Medicina de Familia y Salud Comunal, Universidad Central del Caribe; 1994.

20. Robles R, Moscoso MR, Colon HM, Garcia M, Parilla I. El uso de drogas en los adolescentes escolares. Consulta Juvenil III, 1994-95. Hato Rey, Puerto Rico: Instituto de Investigaciones, Administración de Servicios de Salud Mental y Contra la Adicción, Departamento de Medicina de Familia y Salud Comunal, Universidad Central del Caribe; 1995.

21. Moscoso MR, Parrilla I, Robles RR, Colon HM, Garcia M. El uso de drogas en los escolares puertorriqueños. Consulta Juvenil IV, 1997-98. Hato Rey, Puerto Rico: Instituto de Investigaciones, Administracion de Servicios de Salud Mental y Contra la Adicción, Departamento de Medicina de Familia y Salud Comunal, Universidad Central del Caribe; 1998.

22. American Psychiatric Association (APA). Diagnostic and statistical manual of mental disorders. 4th ed. Text revision. Washington, D.C.: APA; 2000.

23. Whitaker DJ, Miller KS, Clark LF. Reconceptualizing adolescent sexual behavior: beyond did they or didn't they? Fam Plann Perspect. 2000;32(3):111-7.

24. Parrilla IC, Moscoso MR, Velez M, Robles RR, Colon HM. El ambiente interno y externo del adolescente puertorriqueño en el uso del alcohol, las drogas y la violencia. Bol Asoc Med P R. 1997;89(7-9):146-9.

25. Jessor R, Jessor SL. Problem behavior and psychosocial development: a longitudinal study of youth. New York: Academic Press; 1977.

26. Jessor R. Problem-behavior theory, psychosocial development, and adolescent problem drinking. Br J Addict. 1987;82(4):331-42. 
27. Latimer WW, O'Brien MS, McDouall J, Toussova O, Floyd LJ, Vazquez M. Screening for "substance abuse" among school-based youth in Mexico using the Problem Oriented Screening Instrument (POSIT) for Teenagers. Subst Use Misuse. 2004;39(2):307-29.

28. O'Malley PM, Johnston LD, Bachman JG, Schulenberg JE. A comparison of confidential versus anonymous survey procedures: effects on reporting of drug use and related attitudes and beliefs in a national study of students. J Drug Issues. 2000;30(1):35-54.

29. Winters KC, Henly GA. Personal Experience Inventory and manual. Los Angeles: Western Psychological Services; 1989.

30. Winters KC, Henly GA. Adolescent Diagnostic Interview and manual. Los Angeles: Western Psychological Services; 1993.

31. Winters KC, Latimer WW, Stinchfield RD. Adolescent treatment. In: Ott PJ, Tarter RE, Ammerman RT, eds. Source book on substance abuse: etiology, epidemiology, assess- ment, and treatment. New York: Allyn and Bacon; 1999. Pp. 350-61.

32. Harrison PA, Fulkerson JA, Beebe TJ. DSM-IV substance use disorder criteria for adolescents: a critical examination based on a statewide school survey. Am J Psychiatry. 1998; 155:486-92.

33. Hasin DS, Schuckit MA, Martin CS, Grant BF, Bucholz KK, Helzer JE. The validity of DSMIV alcohol dependence: what do we know and what do we need to know? Alcohol Clin Exp Res. 2003;27:244-52.

34. Pollock NK, Martin CS. Diagnostic orphans: adolescents with alcohol symptoms who do not qualify for DSM-IV abuse or dependence diagnoses. Am J Psychiatry. 1999;156:897-901.

35. Rosner B. Fundamentals of biostatistics. 5th ed. Pacific Grove, CA: Duxbury; 2000.

36. SPSS Inc. SPSS 13.0 for Windows. Chicago: SPSS Inc.; 2004.

37. StataCorp. Intercooled Stata 8.0 for Windows. College Station, Texas: StataCorp LC; 2005.
38. Burack R. Teenage sexual behaviour: attitudes towards and declared sexual activity. Br J Fam Plann. 1999;24(4):145-8.

39. Grant JD, Scherrer JF, Lynskey MT, Lyons MJ, Eisen SA, Tsuang MT, et al. Adolescent alcohol use is a risk factor for adult alcohol and drug dependence: evidence from a twin design. Psychol Med. 2006;36(1):109-18.

40. Steinhausen HC, Metzke CW. The validity of adolescent types of alcohol use. J Child Psychol Psychiatry. 2003;44(5):677-86.

41. Cox RG, Zhang L, Johnson WD, Bender DR. Academic performance and substance use: findings from a state survey of public high school students. J Sch Health. 2007;77(3): 109-15.

Manuscript received on 20 November 2006. Revised version accepted for publication on 18 January 2008.

RESUMEN Objetivos. Se buscó: a) categorizar a los jóvenes según su nivel de consumo de alcohol y el número de síntomas de abuso y dependencia del alcohol definidos en el Manual diagnóstico y estadístico de los trastornos mentales (DSM-IV); y b) analizar si esas categorías están asociadas con otros comportamientos problemáticos de los jóvenes (consumo de marihuana, relaciones sexuales y arrestos o problemas con la ley).

Métodos. Estudio transversal basado en una encuesta aplicada a 972 jóvenes que asistían a una escuela secundaria y una preparatoria en San Juan, Puerto Rico. Los jóvenes se categorizaron según el consumo de bebidas alcohólicas y los problemas del alcoholismo. Se buscaron asociaciones entre esas categorías y el consumo de marihuana y las relaciones sexuales — ambas en toda la vida-, así como con los arrestos o problemas con la ley en el año anterior a la encuesta. A partir de los resultados, las ocho categorías iniciales según el consumo de alcohol se reagruparon en seis.

Resultados. Prácticamente en todos los grupos caracterizados por un mayor consumo de bebidas alcohólicas y mayores problemas del alcoholismo se observó un aumento en la prevalencia de consumo de marihuana y la probabilidad de haber tenido relaciones sexuales, ambas en toda la vida, así como de haber tenido problemas con la ley durante el año anterior.

Conclusiones. Conocer las variaciones en el consumo de bebidas alcohólicas y los problemas del alcoholismo puede servir para medir el grado en que los jóvenes pueden involucrarse en diversos comportamientos de mayor riesgo y avanzar a formas más peligrosas de consumo de alcohol y drogas.

Palabras clave Conducta del adolescente, trastornos relacionados con el alcohol, alcoholismo, clasificación, asunción de riesgos, Puerto Rico. 